\title{
Effects of Paclobutrazol on Royal Palm (Roystonea regia) Trunk and Height Growth
}

\author{
A.D. Ali and Shawn C. Bernick
}

\begin{abstract}
Paclobturazol is a plant growth regulator which reduces cell elongation and growth. It is commonly used in reducing the growth of herbaceous plants and woody dicots. It has also shown activity against young palms, such as oil and date palms. The effects of basal drench treatments applied annually or as a single application on mature Royal palms (Roystonea regia) were studied over a three-year period. No significant effects were noted on lateral trunk growth. Paclobutrazol treatments resulted in slower vertical growth than in palms not receiving a treatment. However, even at 36 MAT, the average reduction in vertical growth (approx. $50 \mathrm{~cm}$ ) was still not horticulturally significant relative to the overall palm height of approximately $7 \mathrm{~m}$. Royal palms may attain heights up to $24 \mathrm{~m}$ when mature. It is recommended that they not be planted within $7 \mathrm{~m}$ of utility lines especially considering regulating their vertical growth is not a practical option.

Key Words. Growth; Growth Regulators; Height Control; Paclobturazol; Royal Palm; Roystonea regia.
\end{abstract}

The Royal palm (Roystonea regia) is a valued specimen in Florida, U.S. landscapes. Part of their appeal is the smooth, grey trunk topped by a glossy green crown shaft and a dark green canopy consisting of feathery fronds up to $3.3 \mathrm{~m}$ long. This stately palm can grow quickly under the appropriate conditions of sun, soil moisture, and fertility, and reach heights of $24 \mathrm{~m}$. Occasionally, these palms may be found near or growing under utility lines. Slowing their vertical growth rate is desirable in those circumstances.

Paclobutrazol is a plant growth regulator which inhibits gibberellin synthesis in apical meristematic tissue, thus reducing cell elongation and growth (Blaedow 2003).

This growth regulator has been available for decades and is commonly used in floriculture as well as in reducing growth of various woody dicots (Barrett and Nell 1983; Ruter 1994; Bai et al. 2004; Watson 2006). Paclobutrazol has been investigated for reducing plant growth near utility lines and in Rights-of-Way as well, in order to minimize power interruptions (Bowles 1985). Various application methods have been reported including foliar treatment, bark banding, trunk injection, and basal soil drench (Tamsberg 1990).

Carvajal et al. (1998) showed that paclobutrazol reduces height, rachis length, and leaf area when applied as a soil drench to nursery stock oil palm (Elaeis sp.). El-Hodairi et al. (1998) evaluated paclobutrazol effects on the date palm (Phoenix dactylifera). They showed that sequential crown drenches directed at the growing bud at 30 day intervals, reduced tree height in thee-year-old date palms. Hensley and Yogi (1996) investigated the effects of paclobutrazol on selected tropical species. They reported reduced height growth as a result of basal soil drench in Queen palm (Syagrus romanzoffiana) and Manila palm (Adonidia merrillii), 11 months after treatment.

The effects of other growth regulators on palms have also been reported by various researchers. Broschat and Donselman (1986) found monthly sprays of Ethephon retarded elongation and reduced the incidence of flowering in one-year-old Chamaedorea seifrizii. Similarly, Fisher (1980) reported leaf size reduction with Ethephon sprays or leaf tip treatments in young Caryota, Chamaedorea, Chrysalidocarpus, Phoenix, and Rhapis. Fisher and Theobald (1989) evaluated long-term effects of trunk injection with gibberellin or cytokinin in mature coconut trees. Neither product induced vegetative proliferation intended for mass propagation of coconuts. The multi-year study reported herein was conducted to evaluate the effects of paclobutrazol on mature Royal palms.

\section{MATERIALS AND METHODS}

Mature palms growing in a well-maintained landscape setting in Naples, FL, were selected for this study. The palms were approximately $7 \mathrm{~m}$ tall with an average diameter at breast height $(\mathrm{DBH}), 1.4 \mathrm{~m}$ above ground level, of $38 \mathrm{~cm}$. Soil texture was sandy with $\mathrm{pH} 7.2$ and $3.2 \%$ organic matter. Paclobutrazol (Cambistat ${ }^{\circledR}$ 2SC, Rainbow Treecare Scientific Advancements, Minnetonka, MN) treatments were as follows: 1) Cambistat $2 \mathrm{SC}$ at $1.6 \mathrm{gm}$ ai/cm trunk DBH basal soil drench applied once on February 6, 2007; 2) Cambistat $2 \mathrm{SC}$ at $1.6 \mathrm{gm}$ ai $/ \mathrm{cm}$ trunk DBH basal soil drench applied annually on February 6, 2007; February 5, 2008; and February 6, 2009; 3) Untreated Check not receiving any treatment. Paclobutrazol was mixed according to label instructions, and treatments were applied as a basal drench with a watering can. Drench volume was 7.6 L/tree. Mulch (pine needles) at the bases of palms were pulled back prior to drench application then replaced afterwards. The trees were fertilized three times per year with $103 \mathrm{gm}$ each of a granular, slowrelease nitrogen fertilizer (7-2-14), applied near the base. 
Palm height (clear trunk height) was determined with a clinometer (Bunton Clino Master model CM 66 LA). The reference point was the base of the crown sheath (most recent visible frond scar). Determinations were made from the same fixed distance $(10 \mathrm{~m})$ and direction from each palm. In addition, digital images were used to monitor tree height. Palms were photographed with a permanent reference point (i.e., building) in the background. Trunk size (DBH) was determined with a measuring tape (Keson diameter tape rule). Evaluations of height differences and DBH were made pre-treatment, 12, 24, and 36 months after treatment (MAT) during February each year.

The study was initiated in February 2007 and completed February 2010. Experimental design was a randomized complete block design with 10 replicate palm trees per treatment. Data were analyzed with ANOVA and mean separation via Student-Newman-Keuls test at $P=0.05$.

\section{RESULTS}

No noticeable differences in lateral trunk growth (trunk diameter) were found among treatments (Table 1). Mature palms normally grow from the top without additional increase in girth. Any minute differences in reported data are likely due to measurement error. Significant differences were found in tree height at 24 and 36 MAT (Table 2). Palms receiving annual applications of paclobutrazol showed a trend for slower growth (though not statistically different) than those receiving a single application. Both paclobutrazol treatments resulted in slower vertical growth than in palms not receiving a treatment.
However, even at 36 MAT, the average reduction in vertical growth (approx. $50 \mathrm{~cm}$ ) was still not horticulturally significant relative to the overall palm height of approximately $7 \mathrm{~m}$.

\section{DISCUSSION}

Annual basal drenches with paclobutrazol slightly reduced vertical growth of mature Royal palms over a 36-month period. Even though it is an effective growth regulator on woody dicots (Barrett and Nell 1983; Ruter 1994; Blaedow 2003), paclobutrazol did not result in an appreciable effect on mature Royal palms throughout the duration of this study. In order to prevent power interruptions, it is recommended that Royal palms be planted at least $7 \mathrm{~m}$ away from power lines. Planting these palms directly underneath the lines will result in future problems as the trees attain heights of $24 \mathrm{~m}$ or more.

Acknowledgments. We wish to express gratitude to Chris Andrews with Bay Colony Community Association for providing a site for this study. This work was supported, in part, by a grant from Rainbow Treecare Scientific Advancements.

Table 1. Effects of paclobutrazol basal drench on mature Royal Palm lateral trunk growth, Naples, FL, 2007-2010.

\begin{tabular}{llll}
\hline & \multicolumn{2}{c}{ Trunk Diameter at Breast Height $(\mathrm{cm})^{\mathrm{z}}$} \\
\cline { 2 - 4 } Treatment & 2007 & 2008 & 2009 \\
\hline Paclobutrazol single application & $41.4 \mathrm{a}$ & $41.4 \mathrm{a}$ & 2010 \\
Paclobutrazol annually & $35.6 \mathrm{a}$ & $35.6 \mathrm{a}$ & $41.4 \mathrm{a}$ \\
Untreated check & $43.9 \mathrm{a}$ & $43.9 \mathrm{a}$ & $35.6 \mathrm{a}$ \\
\hline
\end{tabular}

${ }^{\mathrm{z}}$ Within rows, means followed by the same letter are not significantly different $(P>0.05)$ as determined by Student-Neuman-Keuls test.

Table 2. Effects of paclobutrazol basal drench on mature Royal Palm vertical growth, Naples, FL, 2007-2010

\begin{tabular}{|c|c|c|c|}
\hline \multirow[b]{2}{*}{ Treatment } & \multicolumn{3}{|c|}{ Vertical Growth $(\mathrm{cm})^{\mathrm{z}}$} \\
\hline & $\begin{array}{l}2008 \\
(12 \mathrm{MAT})^{\mathrm{y}}\end{array}$ & $\begin{array}{l}2009 \\
\text { (24 MAT) }\end{array}$ & $\begin{array}{l}2010 \\
(36 \text { MAT) }\end{array}$ \\
\hline Paclobutrazol single application & $13.7 \mathrm{a}$ & $24.4 \mathrm{ab}$ & $29.0 \mathrm{~b}$ \\
\hline Paclobutrazol annually & $15.2 \mathrm{a}$ & $15.2 \mathrm{~b}$ & $18.3 \mathrm{~b}$ \\
\hline Untreated check & $24.3 \mathrm{a}$ & $42.7 \mathrm{a}$ & $51.8 \mathrm{a}$ \\
\hline
\end{tabular}

${ }^{\mathrm{z}}$ Measurement of the difference between height during the indicated year less the initial height in 2007 (pretreatment). Within columns, means followed by the same letter are not significantly different $(P>0.05)$ as determined by Student-Neuman-Keuls test.

y Months After Treatment. 


\section{LITERATURE CITED}

Bai, S., W. Chaney, and Y. Qi. 2004. Response of cambial and shoot growth in trees treated with paclobutrazol. Journal of Arboriculture 30:137-145.

Barrett, J.E., and T.A. Nell. 1983. FICUS BENJAMINA response to growth retardants. Proceedings Florida State Horticulture Society 96:264-265.

Blaedow, R. A. 2003. The fungicidal properties associated with the tree growth regulator paclobutrazol. M.S. Thesis, Purdue Univ., 233 pp.

Bowles, H. 1985. Growth retardant use by utility companies. Journal of Arboriculture 11:59-60.

Broschat, T.K., and H. Donselman. 1986. Effects of several plant growth substances on height, flowering and lateral shoot development of Chamaedorea seifrizii. Principes (Palms) 30:135-137.

Carvajal, E., A. Alvarado, F. Sterling, and J. Rodriguez. 1998. The use of paclobutrazol in oil palm clones during the nursery stage. ASD Oil Palm Papers 18:29-33.

El-Hodairi, M.H., A. Albahi, S.B. Ibrahim, and M.A. Hamza. 1998. Interaction effects of the sequential applications of some growth regulators on the growth of date palm trees (Phoenix dactylifera L.). Proceedings of 1st International Conference of Date Palms pp. 71-84.

Fisher, J.B. 1980. Morphogenetic effects of gibberellins and other growth regulators on palms. pp. 21032. In: C.D. Brickel, D.F. Cutler, and M. Gregory (Eds.). Peraloid monocotyledons. Linnean Society Symposium Series 8, Academic Press, London.

Fisher, J.B., and W.F. Theobald. 1989. Long-term effects of gibberellin and cytokinin on coconut trees. Principes (Palms) 33:5-17.

Hensley, D., and J. Yogi. 1996. Growth regulation of some tropical species. Journal of Arboriculture 22:244-247.

Ruter, J.M. 1994. Growth and landscape establishment of Pyracantha and Juniperus after application of paclobutrazol. HortScience 29:1318-1320.

Tamsberg, J.B. 1990. The use of tree growth regulators at Florida Power \& Light Company. Journal of Arboriculture 16:319-321.

Watson, G.W. 2006. The effect of paclobutrazol treatment on starch content, Mycorrizal colonization, and fine root density of white oak (Quercus alba L.). Journal of Arboriculture 32:114-117.

\author{
A.D. Ali (corresponding author) \\ Technical Advisor \\ Davey Institute \\ The Davey Tree Expert Company \\ 17140 Oak Creek Road \\ Alva, FL 33920, U.S \\ ad.ali@davey.com
}

Shawn C. Bernick

Director of Research and Technical Support

Rainbow Treecare Scientific Advancements

$11571 \mathrm{~K}$-tel Drive

Minnetonka, MN 55343, U.S.
Résumé. Le paclobutrazol est un régulateur de croissance qui diminue l'élongation cellulaire et la croissance. Il est communément utilisé pour diminuer la croissance des plantes herbacées et les dicotylédones ligneux. Il s'est aussi avéré actif contre les jeunes palmiers, tels le palmier à dattes et le palmier à huile. Les effets de traitements par injection annuelle dans le sol au pied de l'arbre ou par une application unique chez les palmiers royaux de Cuba (Roystonea regia) ont été étudiés sur une période de trois ans. Aucun effet significatif n'a été observé sur la croissance latérale des troncs. Les traitements avec le paclobutrazol ont donné une croissance verticale plus faible par rapport aux palmiers non traités. Néanmoins, même avec un traitement à concentration élevée, la réduction moyenne de croissance verticale (environ $50 \mathrm{~cm}$ ) n'était pas significative au niveau horticole en regard de la hauteur totale du palmier qui était d'environ $7 \mathrm{~m}$. Les palmiers royaux de Cuba peuvent atteindre des hauteur allant jusqu'à $24 \mathrm{~m}$ lorsqu'ils sont matures. Il est recommandé qu'ils ne soient pas plantés à l'intérieur d'une distance de $7 \mathrm{~m}$ des réseaux aériens de services publics particulièrement si on considère que tenter de contrôler leur croissance verticale n'est pas une option pratique.

Zusammenfassung. Paclobutrazol ist ein Pflanzenwachstumsregulator, welcher die Elongation von Zellen und damit das Wachstum reduziert. Es wird gewöhnlich zur Wachstumsregulierung von krautartigen und zweikeimblättigen Pflanzen genommen. Es hat auch Auswirkungen auf das Wachstum von jungen Palmen, z. B. öl- und Dattelpalmen, gezeigt Der Einfluss von Wurzelaufguß-Behandlungen, die jährlich oder als eine einmalige Applikation auf ausgewachsene Königspalmen (Roystonea regia) ausgebracht wurden, wird hier in einer dreijährigen Studie untersucht. Es konnte kein signifikanter Einfluss auf das laterale Wachstum festgestellt werden. Paclobutrazol-Behandlungen resultierten in langsamerem vertikalen Wachstum als in Palmen, die keine Behandlung erhielten. Dennoch, auch bei 36 MAT, war die durchschnittliche Reduktion vertikalen Wachstums gartenbaulich nicht relevant in Bezug auf die Gesamthöhe der Palmen von schätzungsweise $7 \mathrm{~m}$. Die Königspalmen können, wenn ausgewachsen, eine Höhe von 24 m erreichen. Es wird empfohlen, daß sie nicht innerhalb von $7 \mathrm{~m}$ von Versorgungsleitung gepflanzt werden, besonders im Hinblick darauf, daß ihre Wachstumsregulierung keine praktikable Möglichkeit darstellt.

Resumen. Paclobturazol es un regulador del crecimiento de las plantas que reduce la elongación celular y el crecimiento. Es comúnmente usado para reducir el crecimiento de herbáceas y dicotiledóneas maderables. También ha mostrado efectividad en palmas jóvenes, tales como palmas datileras y de aceite. Se estudiaron los efectos de tratamientos con zanjas basales aplicadas anualmente o como una sola aplicación en palmas Royal (Roystonea regia) en un período de tres años. No se observaron efectos significativos en el crecimiento de troncos laterales Los tratamientos con Paclobturazol resultaron en menor crecimiento vertica que en palmas que no recibieron el tratamiento. Sin embargo, aún a 36 MAT, la reducción promedio en crecimiento vertical (aprox. $50 \mathrm{~cm}$ ) no fue significativo en el crecimiento total de la palma de aproximadamente $7 \mathrm{~m}$. Las palmas Royal pueden alcanzar alturas hasta $24 \mathrm{~m}$ en su madurez. Se recomienda que no deban ser plantadas dentro de $7 \mathrm{~m}$ de líneas de servicios, especialmente considerando que la regulación de su crecimiento vertical no es una opción práctica. 